\title{
DETECTION OF LATE-ONSET HYPOGONADISM IN MEN WITH CHRONIC INTERNAL DISEASES
}

\author{
Anatolijs Požarskis ${ }^{1, \#}$ and Aivars Lejnieks ${ }^{2,3}$ \\ 1 Private practice, 46 Cietokšña Str., Daugavpils, LV-5401. LATVIA \\ 2 Rīga East University Clinical Hospital, 2 Hipokrāta Str., Rīga, LV-1038, LATVIA \\ ${ }^{3}$ Rīga Stradinš̌ University, 16 Dzirciema Str., Rīga, LATVIA \\ \# Corresponding author: drpozarskis@inbox.lv
}

Contributed by Aivars Lejnieks

\begin{abstract}
Late-onset hypogonadism ( $\mathrm{LOH}$ ) is a clinical and biochemical syndrome associated with age and featured by typical symptoms and reduced blood testosterone level. Among males aged over 30 years, the incidence of androgen deficiency is 7 to $30 \%$. The aim of this study was to investigate the incidence of hypogonadism in patients aged over 40 years with an underlying condition and/or a comorbidity, such as arterial hypertension, Chronic obstructive pulmonary disease (COPD), metabolic syndrome, Type 2 of diabetes mellitus, dyslipidaemia, adiposity in various General practice (GP) and physician-sexologists' offices in Latvia, and to determine the influence of chronic diseases on the development of hypogonadism. Males aged 39 years who turned to family doctors at nine GP were offered to fill in Aging Male Study (AMS) questionnaires used for the diagnostics of late-onset hypogonadism. Males aged 40 years who visited the office of the physician sexologist Anatolijs Požarskis were offered to fill in the same questionnaires. After compiling the data from AMS questionnaires, a group of males exhibiting signs of $\mathrm{LOH}$ were isolated (in total 1222 persons). In these patients, we determined blood testosterone and sex-hormone binding globulin (SHBG) levels. Chronic diseases were found in these men in data evaluation of patient medical records, and after performing physical and laboratory examinations. Late-onset hypogonadism was laboratory-diagnosed in $79 \%$ of patients with signs of late-onset hypogonadism in accordance with the AMS questionnaires and with concomitant diseases and in $4.7 \%$ of patients with signs of late-onset hypogonadism in accordance with the AMS questionnaires and without the aforementioned concomitant diseases. Persons with arterial hypertension, dyslipidaemia, adiposity, metabolic syndrome, COPD and Type 2 of diabetes mellitus had higher chance of developing hypogonadism ( $\mathrm{p}<0.001)$. Arterial hypertension, dyslipidaemia, adiposity, metabolic syndrome, COPD statistically significantly $(\mathrm{p}<0.001)$ decreased the level of total testosterone by $0.47,1.18,0.36,0.67$, and $0.18 \mathrm{ng} / \mathrm{ml}$, respectively, and decreased the level of free testosterone by 2.52, 2.71, 1,69, 6.77, and $4.58 \mathrm{pg} / \mathrm{ml}$, respectively. Type 2 diabetes mellitus had no statistically significant effect on the level of total and free testosterone $(p=0.95, p=0.10)$. The most significant decrease in the level of testosterone was observed in cases of dyslipidemia, COPD and metabolic syndrome. General physicians should pay special attention to patients with this disease, as these patients belong to a group with a high risk of development of expressed $\mathrm{LOH}$ syndrome.
\end{abstract}

Key words: late-onset hypogonadism, testosterone, chronic diseases.

\section{INTRODUCTION}

In recent years, much attention has been paid to the reproductive health of males of different age. An important aspect of male health is the impact of somatic diseases on male gonadal function. Knowledge on the issue of male late-onset hypogonadism, or $\mathrm{LOH}$, is moving forward. It has been shown that with age, the testosterone level gradually decreases even in completely healthy males (Reisman et al., 2015). Moreover, this issue has hardly been studied in the context of comorbidities. 
Testosterone fraction dynamics have been studied in detail in the context of rather prevalent diseases, such as arterial hypertension, diabetes mellitus, dyslipoproteinemia, and metabolic syndrome (Lunenfeld et al., 2015). These diseases are featured by rather unfavourable prognosis regarding high risk of local vascular pathology, reduction of the quality of life, and premature death. A pressing issue is the dynamics of testosterone fractions in cases of chronic obstructive pulmonary disease (COPD) (Karacou et al., 2013; Vertkin et al., 2013).

The aims of our study were: to determine the laboratory-confirmed $\mathrm{LOH}$ prevalence in patients with signs of LOH in accordance with Aging Males Study questionnaire data and arterial hypertension, adiposity, dyslipidaemia, metabolic syndrome, Type 2 diabetes mellitus and COPD; to determine the laboratory-confirmed $\mathrm{LOH}$ prevalence in patients with signs of $\mathrm{LOH}$ in accordance with AMS questionnaire data and without the aforementioned diseases; to determine the effect of the aforementioned chronic diseases on the prospects for hypogonadism development, by study of the effect of these diseases on the total and free testosterone levels in patients with signs of $\mathrm{LOH}$ in accordance with AMS questionnaire data; and to develop recommendations for general practitioners regarding $\mathrm{LOH}$ diagnostics in men over 40 years of age.

\section{MATERIALS AND METHODS}

The cross-sectional study was based on survey of men using the Aging Males' Symptoms questionnaire, or AMS questionnaire, as well as on the assessment of the participants by means of clinical and laboratory methods. The Aging Males' Symptoms questionnaire was recommended to be used in LOH diagnostics by the International Society for the Study of the Aging Male (ISSAM) (Morales and Lunenfeld, 2002). The AMS questionnaire was translated into Latvian and Russian by ISSAM for use in the study. Males with age over 40 years who were referred by general practitioners at nine general practitioner's offices in Latvia due to acute illnesses, exacerbations of chronic disease, or for preventive examinations, and who had agreed to take part in the study, were offered to complete the AMS questionnaire. Males over 40 years of age, who were referred to the physician-sexologist Anatolijs Požarskis' office, were offered to complete the same questionnaire. After the analysis of the AMS questionnaire data, a group of men with signs of $\mathrm{LOH}$ was identified. These patients were offered further participate in the study for determination of blood testosterone and sex hormone building globuline (SHBG) levels. SHBG level should be determined to calculate the level of free testosterone by a special formula (Morales and Lunenfeld, 2002). Men's medical records filled in by the general practitioners were also assessed, and chronic diseases identified in anamnesis of these patients were recorded. The following data in participants' medical records for the last six months were also recorded: blood glucose, total cholesterol, triglycerides, high-density lipoprotein (HDL), and low-density lipoprotein (LDL) levels, and spirometry. If the data were present in a medical record, they were used in our study; if the data were not available, blood glucose, total cholesterol, triglycerides, LDL, and HDL levels were determined in patients. Physical examinations were performed, and the following indicators were determined: arterial blood pressure on both arms; height and weight, body mass index, and waist circumference.

The study group was comprised of patients in whom LOH had been established in accordance with the AMS questionnaire data, and the following diseases were identified $(\mathrm{n}=$ 820): arterial hypertension, dyslipidaemia, adiposity, metabolic syndrome, Type 2 diabetes mellitus, and COPD with or without medication.

The control group was comprised of patients in whom LOH had been established in accordance with the AMS questionnaire data, and in whom arterial hypertension, dyslipidaemia, adiposity, metabolic syndrome, Type 2 diabetes mellitus, and COPD had not been diagnosed $(n=402)$. These patients do not use any medication to treat the above diseases. We used the following diagnostic criteria of somatic pathologies.

Arterial hypertension. We used the currently available hypertension classification system recommended by the European Society of Hypertension and the European Society of Cardiology (Mancia et al., 2013), where the optimal blood pressure (BP) level is considered $<120 / 80 \mathrm{mmHg}$; normal BP: 120-129/80-84 mmHg; high normal BP: 130-139/85-89 mmHg; stage 1 hypertension: 140-159/90-99 mmHg; stage 2 hypertension: 160-179/100-109 mmHg; and stage 3 hypertension: $\geq 180 / \geq 110 \mathrm{mmHg}$. Depending on blood pressure level, risk factors, asymptomatic organ impairment, and presence of concomitant clinical pathology, arterial hypertension, patients were divided into four risk groups of complications: low, moderate, high, and very high risk (Mancia et al., 2013). The study included patients with high and very high risk of complications.

Diabetes mellitus was diagnosed on the basis of the following criteria: repeated measurements of fasting blood glucose levels $>7.0 \mathrm{mmol} / \mathrm{l}(120 \mathrm{mg} \%)$ or $>11.1 \mathrm{mmol} / \mathrm{l}(200 \mathrm{mg}$ $\%)$ two hours after 75 g glucose load.

Obesity diagnosis was carried out in accordance with modern WHO classification principles based on the body mass index (Anonymous, 2000). According to the body mass index, normal weight corresponds to $18.5-24.99 \mathrm{~kg} / \mathrm{m}^{2}$, overweight - to $25-29.99 \mathrm{~kg} / \mathrm{m}^{2}$, obesity - to $30-39.99 \mathrm{~kg} / \mathrm{m}^{2}$, severe obesity $-\geq 40 \mathrm{~kg} / \mathrm{m}^{2}$.

Dyslipidaemia was determined according to the following metabolic parameters: total cholesterol concentration $>5.0$ $\mathrm{mmol} / \mathrm{l}$, triglyceride level $>1.7 \mathrm{mmol} / \mathrm{l}$, HDL cholesterol concentration $<1.0 \mathrm{mmol} / \mathrm{l}$, and LDL cholesterol concentration $>3.0 \mathrm{mmol} / \mathrm{l}$.

Metabolic syndrome was diagnosed if at least three of the following criteria had been established (Alberti et al., 
2009): arterial hypertension (characteristic values of arterial blood pressure $>130 / 85 \mathrm{~mm} / \mathrm{Hg}$, or patients with arterial hypertension using antihypertensive medication); triglycerides $>1.7 \mathrm{mmol} / \mathrm{l}$, or medical treatment of hypertriglyceridemia; fasting blood glucose level $>5.6 \mathrm{mmol} / \mathrm{l}$, or medical treatment of hyperglycaemia; HDL level $<1.0$ $\mathrm{mmol} / \mathrm{l}$; waist circumference $94 \mathrm{~cm}$, which is a sign of abdominal obesity.

Chronic obstructive pulmonary disease. Moderately severe COPD was diagnosed according to the following criteria: anamnesis data (long-term smoking period, or long-term exposure to substances irritant to respiratory system), complaints (dyspnoea at physical exertion of moderate intensity, productive cough, periods with cough and high temperature), physical examination (vesiculotympanitic resonance to percussion, weakened respiration, dry noise to auscultation), instrumental examination (measurement of forced expiratory volume in one second (FEV1) 50 to $80 \%$ of the normal at FEV1/FVC $<0.70$, and a bronchodilation test where after the inhalation of salbutamol FEV1 increased on average by $7.6 \%$, which is a sign of an irreversible bronchial obstruction).

Laboratory diagnosis of $\mathbf{L O H}$ was established by means of immunoenzymatic method using the Multiskan Plus photometer test system at wavelength $450 \mathrm{~nm}$. During the diagnostics, total and free testosterone levels were established and divided into three categories: "normal value", "reduced to the threshold level", and "abnormally low". Following the recommendations of International Society of Andrology (ISA), International Society for The Study of The Aging Male (ISSAM) and European Urology Association (EAU) guidelines in 2006 (the year when our study was started), total and free testosterone levels are considered normal at $>3.46 \mathrm{ng} / \mathrm{ml}$ and $>72.00 \mathrm{pg} / \mathrm{ml}$, reduced to the threshold level - 3.46-2.31 ng/ml and 65.00-72.00 pg/ml, and abnormally low $<2.31 \mathrm{ng} / \mathrm{ml}$ and $\sim 65.00 \mathrm{pg} / \mathrm{ml}$, respectively (Nieschlag et al., 2006).

Non-parametric (percentage and its 95\% confidence interval, cross-tabulation analysis) and parametric descriptive statistical methods (minimum, maximum, average, standard deviation, median) were used to describe the population. The Kolmogorov-Smirnov test was used to determine the normal distribution of parametric indicators. The conditional odds ratio (OR) was calculated using binary logistic regression to determine the independent influence of chronic diseases and age on hypogonadism. Binary logistic regression was also used to search for different associations between AMS symptoms and hypogonadism. Linear regression was used to determine the independent influence of chronic diseases and age on total and free testosterone levels. To evaluate the significance of the differences between two sets of data, the Student's t-criterion was used. The difference between the parameters was considered to be statistically significant, if the t-value is $\geq 2$ (in this case $p<$ $0.05)$. Student's t-criterion was used to identify significant differences in quantitative parameters of investigated processes. Statistical data processing was performed using
SPSS (Statistical Package for the Social Sciences) 20.0 software. MS Excel was used to create figures. The results were considered to be statistically significant if $p<0.05$.

\section{RESULTS}

The study comprised 820 patients with chronic internal diseases. The following somatic and cardiac pathologies were recorded in patients: arterial hypertension in 320 cases (39\%), obesity in 407 cases (49.6\%), Type 2 diabetes mellitus in 67 patients $(8.2 \%)$, dyslipidaemia in 681 patients $(83 \%)$, metabolic syndrome in 139 patients $(17 \%)$, and COPD in 107 patients (13\%). The patients were in the age range of 40 to 70 years, and were distributed in the following age-defined patient groups: $40-45$ years of age (81 patient, or $9.9 \%$ ), 46-50 years of age (93 patients, or $11.3 \%$ ), $51-55$ years of age (372 patients, or $45.4 \%), 56-60$ years of age (157 patients, or $19.2 \%), 61-65$ years of age ( 85 patients, or $10.4 \%)$, and $66-70$ years of age (32 patients, or $3.9 \%$ ) (Table 1).

402 men without any observed chronic concomitant disease were enrolled in the study. Male age characteristics were as follows: 40-45 years of age - 49 patients, 46-50 years of age -51 patients, 50-55 years of age -83 patients, 56-60 years of age -68 patients, 61-65 years of age -70 patients, and 66-70 years of age -81 patients.

According to clinical and laboratory data, hypogonadism was found in 669 patients $(54.7 \%$ of 1222 study participants). In patient groups with chronic comorbidities, hypogonadism was found in 650 patients (79\% of 820 study participants). It was found in men without concomitant diseases in 19 cases (4.7\% of 402 participants in the group). The prevalence of hypogonadism was statistically significantly higher in the patient group with concomitant diseases $(p<0.05)$.

The relationship between hypogonadism and chronic diseases and age was investigated using single and multiple factor analysis. The obtained results are shown in Table 2 . Persons with dyslipidaemia, adiposity, arterial hypertension, metabolic syndrome, COPD and Type 2 diabetes mellitus

Table 1

AGE AND CLINICAL CHARACTERISTICS OF PATIENTS ENROLLED IN THE STUDY

\begin{tabular}{c|c|c|c|c|c|c|c}
\hline $\begin{array}{c}\text { Age } \\
\text { (years) }\end{array}$ & AH & ADPS & DM & Dyslp. & COPD & MS & Total \\
\hline $40-45$ & 30 & 45 & 2 & 54 & 12 & 33 & 176 \\
$46-50$ & 52 & 65 & 14 & 97 & 10 & 25 & 263 \\
$51-55$ & 40 & 48 & 9 & 102 & 24 & 39 & 262 \\
$56-60$ & 44 & 76 & 15 & 147 & 16 & 31 & 329 \\
$61-65$ & 58 & 79 & 14 & 140 & 21 & 5 & 317 \\
$66-70$ & 96 & 94 & 13 & 141 & 24 & 6 & 374
\end{tabular}

$\mathrm{AH}$, arterial hypertension; ADPS, adiposity; DM, diabetes mellitus; Dyslp., dyslipidaemia; ED, erectile dysfunction; COPD, chronic obstructive pulmonary disease; MS; metabolic syndrome 
SINGLE AND MULTIPLE FACTOR ANALYSIS OF THE RELATIONSHIP BETWEEN HYPOGONADISM AND CHRONIC DISEASES AND AGE IN COMPARISON TO THE CONTROL GROUP

\begin{tabular}{|c|c|c|c|c|c|c|}
\hline Independent characteristic & $\mathrm{mOR}$ & $95 \% \mathrm{CI}$ & $p$ & $\mathrm{cOR}$ & $95 \% \mathrm{CI}$ & $p$ \\
\hline Dyslipidaemia & 16.90 & $12.72-22.46$ & $<0.001$ & 15.80 & $10.64-23.46$ & $<0.001$ \\
\hline Adiposity & 6.81 & $5.06-9.16$ & $<0.001$ & 2.75 & $1.80-4.20$ & $<0.001$ \\
\hline Arterial hypertension & 6.08 & $4.39-8.43$ & $<0.001$ & 3.68 & $2.34-5.78$ & $<0.001$ \\
\hline Metabolic syndrome & 8.99 & $5.01-16.10$ & $<0.001$ & 4.66 & $2.33-9.32$ & $<0.001$ \\
\hline COPD & 3.98 & $2.39-6.62$ & $<0.001$ & 24.40 & $11.83-50.34$ & $<0.001$ \\
\hline Type 2 diabetes mellitus & 2.03 & $1.18-3.50$ & 0.01 & 1.47 & $1.24-1.92$ & 0.03 \\
\hline Age & 1.07 & $1.05-1.08$ & $<0.001$ & 1.13 & $1.11-1.16$ & $<0.001$ \\
\hline
\end{tabular}

mOR, marginal odds ratio; cOR, conditional odds ratio; CI, confidence interval; p, level of significance; n, absolute number

had higher chance of developing hypogonadism $(p<0.001$ in cases of dyslipidaemia, adiposity, arterial hypertension, metabolic syndrome, and COPD, and $p=0.03$ for diabetes mellitus).

Association between age hypogonadism was also statistically significant $(p<0.001)$. Regardless of whether a man had one of the chronic diseases, with an increase in age by one year, the chances for a patient to develop hypogonadism increased by 1.13 -fold, or by $13 \%$.

The study found that the dyslipidaemia and COPD increased the odds of developing hypogonadism (15.80- and 24.40-fold, respectively).

Using single and multiple factor analysis, the relationship between total testosterone and chronic diseases and age was determined (Table 3). Dyslipidaemia, adiposity, arterial hypertension, metabolic syndrome and COPD was statistically significantly $(p<0.001)$ associated with decreased level of total testosterone. Type 2 diabetes mellitus had no statistically significant association with the level of total testosterone $(p=0.95)$.
Age also had an important role in reducing the level of total testosterone. An increase of age by one year was associated with decrease of the level of total testosterone by 0.03 units $(p<0.001)$.

Dyslipidaemia and COPD were associated with decreased level of total testosterone, regardless of other diseases and age; presence of these diseases decreased the level of total testosterone by 1.18 units.

The relationship between free testosterone and chronic diseases and age is represented in Table 4. Dyslipidaemia, adiposity, arterial hypertension, metabolic syndrome and COPD were statistically significantly $(p<0.001)$ associated with decreased levels of free testosterone. Type 2 diabetes mellitus was associated with decreased level of free testosterone by 1.92 units, but this indicator is not statistically significant. Since one-factor analysis of the influence of Type 2 diabetes mellitus on testosterone level showed lack of statistical significance, Type 2 diabetes mellitus was not further included in the multiple factor analysis model.

Table 3

SINGLE AND MULTIPLE FACTOR ANALYSIS OF THE RELATIONSHIP BETWEEN TOTAL TESTOSTERONE AND CHRONIC DISEASES AND AGE

\begin{tabular}{|c|c|c|c|c|c|c|}
\hline Independent characteristic & $\begin{array}{l}\text { Regression } \\
\text { coefificient }\end{array}$ & $95 \% \mathrm{CI}$ & $p$ & $\begin{array}{l}\text { Regression coeffi- } \\
\text { cient (conditioinal) }\end{array}$ & $95 \% \mathrm{CI}$ & $p$ \\
\hline Dyslipidaemia & -1.64 & $\begin{array}{l}-1.53 \\
-1.75\end{array}$ & $<0.001$ & -1.18 & $\begin{array}{l}-1.06 \\
-1.30\end{array}$ & $<0.001$ \\
\hline Adiposity & -1.12 & $\begin{array}{l}-0.97 \\
-1.26\end{array}$ & $<0.001$ & -0.36 & $\begin{array}{l}-0.24 \\
-0.48\end{array}$ & $<0.001$ \\
\hline Arterial hypertension & -1.10 & $\begin{array}{r}-0.94 \\
-1.25\end{array}$ & $<0.001$ & -0.47 & $\begin{array}{l}-0.35 \\
-0.59\end{array}$ & $<0.001$ \\
\hline Metabolic syndrome & -1.18 & $\begin{array}{l}-0.96 \\
-1.40\end{array}$ & $<0.001$ & -0.67 & $\begin{array}{l}-0.50 \\
-0.85\end{array}$ & $<0.001$ \\
\hline COPD & -1.00 & $\begin{array}{l}-0.75 \\
-1.25\end{array}$ & $<0.001$ & -1.18 & $\begin{array}{l}-1.01 \\
-1.36\end{array}$ & $<0.001$ \\
\hline Type 2 diabetes mellitus & -0.56 & $\begin{array}{l}-0.25 \\
-0.88\end{array}$ & 0.001 & 0.007 & $\begin{array}{c}-0.22 \\
0.23\end{array}$ & 0.95 \\
\hline Age & -0.03 & $\begin{array}{l}-0.03 \\
-0.04\end{array}$ & $<0.001$ & -0.03 & $\begin{array}{l}-0.03 \\
-0.04\end{array}$ & $<0.001$ \\
\hline
\end{tabular}

\footnotetext{
* The following factors were analysed: other investigated diseases, patient's age.
} 
SINGLE AND MULTIPLE FACTOR ANALYSIS OF THE RELATIONSHIP BETWEEN FREE TESTOSTERONE AND CHRONIC DISEASES AND AGE

\begin{tabular}{|c|c|c|c|c|c|c|}
\hline $\begin{array}{l}\text { Independent } \\
\text { characteristic }\end{array}$ & $\begin{array}{l}\text { Regression } \\
\text { coefficient }\end{array}$ & $95 \% \mathrm{CI}$ & $p$ & $\begin{array}{c}\text { Regression coeffi- } \\
\text { cient (condi-tioinal) }\end{array}$ & $95 \% \mathrm{CI}$ & $p$ \\
\hline Dyslipidaemia & -5.86 & $\begin{array}{l}-4.87 \\
-6.85\end{array}$ & $<0.001$ & -2.71 & $\begin{array}{l}-1.64 \\
-3.78\end{array}$ & $<0.001$ \\
\hline Adiposity & -4.53 & $\begin{array}{l}-3.45 \\
-5.60\end{array}$ & $<0.001$ & -1.69 & $\begin{array}{l}-0.57 \\
-2.81\end{array}$ & $<0.001$ \\
\hline Arterial hypertension & -5.34 & $\begin{array}{l}-4.20 \\
-6.49\end{array}$ & $<0.001$ & -2.52 & $\begin{array}{l}-1.41 \\
-3.64\end{array}$ & $<0.001$ \\
\hline Metabolic syndrome & -7.08 & $\begin{array}{l}-5.49 \\
-8.67\end{array}$ & $<0.001$ & -6.77 & $\begin{array}{l}-5.20 \\
-8.34\end{array}$ & $<0.001$ \\
\hline COPD & -3.32 & $\begin{array}{l}-1.49 \\
-5.15\end{array}$ & $<0.001$ & -4.58 & $\begin{array}{l}-2.97 \\
-6.19\end{array}$ & $<0.001$ \\
\hline Type 2 diabetes mellitus & -1.92 & $\begin{array}{l}-4.20 \\
-0.36\end{array}$ & 0.10 & - & - & - \\
\hline Age & -0.30 & $\begin{array}{l}-0.25 \\
-0.36\end{array}$ & $<0.001$ & -0.34 & $\begin{array}{l}-0.28 \\
-0.39\end{array}$ & $<0.001$ \\
\hline
\end{tabular}

* The following factors were analysed: other investigated diseases, patient's age.

Men's age also had an important role in reducing the level of free testosterone. An increase by one year of age was associated with decrease of the level of free testosterone by 0.34 units $(p<0.001)$.

\section{DISCUSSION}

With age, a man's body undergoes changes that lead to decrease in concentration of testosterone: decrease in the number of testosterone-synthesising Leydig cells in testes, decrease in the density of luteinising hormone receptors, impairments in the controlling communication of the hypothalamic-pituitary system, the enzyme that ensures testosterone metabolic synthesis pathway, and decrease in concentration and activity of this enzyme. With the reduction of testosterone level, chronic diseases start to develop (Scweiger et al., 1999; Jockenhovel, 2004; Isidori et al., 2005; Lester and Mason, 2015). On the other hand, chronic diseases can cause testosterone deficiency, or speed up its development. For example, in patients with visceral adiposity, fat cells synthesise biologically active substances, which, being involved in metabolic processes, reduce testosterone synthesis as a result (Butrova, 1999; Požarskis and Ërenpreiss, 2010). In men with reduced libido or erectile dysfunction, the frequency of sexual intercourse is reduced, which, in turn, increases the testosterone deficiency even more. This forms a vicious circle: testosterone deficiency causes chronic concomitant diseases, and concomitant diseases increase the testosterone deficiency even more.

Arterial hypertension was established in $26 \%$ of the participants $(n=1222)$ and $39 \%$ of the subjects with concomitant diseases $(n=820)$ in our study. LOH was found in patients with hypertension more frequently than in normotensive patients. Men with arterial hypertension had 3.68-fold higher odds of developing hypogonadism compared to men without this condition. Regardless of other diseases and men's age, arterial hypertension decreased the level of both total and free testosterone by 0.47 and 2.52 units, respectively. Although the literature data provide evidence on the connection of $\mathrm{LOH}$ in patients with metabolic syndrome and its components, i.e. adiposity or dyslipidaemia (Blaya et al., 2016), as well as the connection of testosterone deficiency with cardiovascular diseases and mortality risk (Lester and Mason, 2015), there have been too limited data on the prevalence of hypogonadism in patients with arterial hypertension until now. The European Male Ageing Study (launched in 2003) investigated health, chronic diseases, and the level of sex steroids in over 3000 men in the age group of 40 to 79 years. Arterial hypertension was diagnosed in $28 \%$ of the study participants (both hypogonadal and eugonadal). In patients with hypogonadism, systolic blood pressure was statistically significantly increased, but diastolic did not change (Tajar et al., 2012). Similar results were obtained in the Massachusetts Male Aging study in the USA. In that study, arterial hypertension was found in $36 \%$ of the patients. It was demonstrated that in patients with hypogonadism both systolic and diastolic blood pressure was higher than in patients with a normal testosterone level (Feldman et al., 1994). In our study, arterial hypertension was observed almost as frequently as in the studies described above. Our study results are in line with the studies described above, as testosterone deficiency was more frequently observed in patients with arterial hypertension compared with those without hypertension.

Adiposity was diagnosed in $33 \%$ of participants $(n=1222)$ and in $49.6 \%$ of participants with concomitant diseases $(n=$ 820). LOH was observed more frequently in patients with adiposity than in those with normal weight, as described in the literature. Several studies have demonstrated a direct correlation of testosterone deficiency with adiposity. For example, European Male Ageing Study demonstrated that patients with $\mathrm{LOH}$ had an increased body mass index and/or 
waist circumference. In addition, a direct correlation between body weight and testosterone indicators was shown. A decrease of body weight by more than $10 \%$ was associated with increase of total testosterone level by $2.9 \mathrm{nmol} / \mathrm{l}$ $(0.84 \mathrm{ng} / \mathrm{ml})$ on average; when body weight increased by more than $10 \%$, total testosterone level decreased by $2.4 \mathrm{nmol} / \mathrm{l}(0.69 \mathrm{ng} / \mathrm{ml})$ on average. If body weight differences were in the range of up to $10 \%$, differences in testosterone level were not statistically significant (Lester and Mason, 2015). The relationship of LOH with adiposity is also described in other publications. On the one hand, testosterone deficiency causes fat accumulation; on the other hand, fat cells produce active substances that reduce the synthesis of testosterone (Butrova, 1999). As a result of this bilateral process, health condition deteriorates progressively, and adiposity complications occur: metabolic syndrome, Type 2 diabetes mellitus, arterial hypertension, coronary and heart disease (Phillips et al., 1994; Simon et al., 1997; Ohlsson et al., 2011). In our study we concluded that men with adiposity have a 2.75-fold higher chance of suffering from hypogonadism compared to men who do not have adiposity $(p<0.001)$. We also observed that, regardless of other diseases and age, adiposity statistically significantly $(p<0.001)$ decreased the level of both total testosterone by $0.36 \mathrm{ng} / \mathrm{ml}$, and free testosterone by $1.69 \mathrm{pg} / \mathrm{ml}$. These results are similar to those in the European Male Ageing Study, where a direct correlation between body weight and testosterone levels was found.

The proportion of adiposity in men aged 40-70 (33\%) in our study was similar to data from clinical trials in Europe and in the United States (Lester and Mason, 2015, Feldman et al., 1994). In these studies, obesity in men aged 40 years and older has been found in $23.9 \%$ and $40 \%$ of the cases, respectively. According to Eurostat data, in the European Union countries the proportion of adults (aged 18 years and over) who were considered to be overweight varied in 2014 between $53.6 \%$ in the Netherlands and $67.5 \%$ in Croatia for men. Adiposity generally increased with age. The age group 18 to 24 years had the lowest share of the overweight population, while the 65 to 74 year group had the highest share (Anonymous, 2014). The large prevalence of obesity in Latvia may be explained by the fact that "Western" eating habits are spreading increasingly in Latvia: more fast food is used.

Type 2 diabetes mellitus was diagnosed in $5.5 \%$ of the study participants (both with and without comorbidities, $\mathrm{n}=$ 1222) and in $8.2 \%$ of participants with concomitant diseases $(\mathrm{n}=820)$. Our data are similar to the findings of the European Male Ageing Study, where Type 2 diabetes was found in $6.6 \%$ of men over 40 years of age. We diagnosed $\mathrm{LOH}$ in $67.2 \%$ of the patients with Type 2 diabetes mellitus. A statistically significant association of Type 2 diabetes mellitus with hypogonadism was observed $(p=0.03)$; Type 2 diabetes mellitus increased the odds of developing hypogonadism by approximately 1.5 times, but no statistically significant effect of Type 2 diabetes mellitus on the levels of total and free testosterone ( $p=0.10, p=0.95$ ) was found. How- ever, the high proportion of $\mathrm{LOH}$ in Type 2 diabetes mellitus patients is in line with the literature data mentioning that testosterone deficiency increases the risk of development of metabolic syndrome and Type 2 diabetes mellitus (Simon et al., 1997; Ohlsson et al., 2011). In a study in which 103 male patients with Type 2 diabetes mellitus were involved, Dhindsa with co-authors found that hypogonadism occurred in $33 \%$ of men. A statistically significant correlation between body mass index and free testosterone level was shown; the higher the BMI, the lower the free testosterone level (Dhindsa et al., 2004). Chandel with co-authors determined the concentration of testosterone in 38 young men (mean age $26.45 \pm 0.89$ years) with Type 1 diabetes mellitus and 24 young men (mean age $27.87 \pm 0.97$ years) with Type 2 diabetes mellitus. Hypogonadism was established in $58 \%$ of patients with Type 2 diabetes mellitus. In Type 1 diabetes mellitus patients, hypogonadism occurred in $8 \%$ of the cases only. The authors concluded that the level of testosterone was lower in Type 2 diabetes mellitus patients compared to Type 1 diabetes mellitus patients, and that the prevalence of hypogonadism was very high in Type 2 diabetes mellitus patients (Chandel et al., 2008). Similar results were obtained by Tomar with co-authors in a study comprised of 15 patients with Type 1 diabetes mellitus patients and 50 patients with Type 2 diabetes mellitus. The levels of testosterone and free testosterone in patients with Type 1 diabetes mellitus were within the normal range, while in patients with Type 2 diabetes mellitus, total testosterone level was decreased in $48 \%$ of cases, and free testosterone level in $26 \%$ of the cases. Consequently, hypogonadism was common in Type 2 diabetes mellitus patients, but not in men with Type 1 diabetes mellitus (Tomar et al., 2006). The fact that our study revealed no statistically significant influence of Type 2 diabetes mellitus on total and free testosterone levels, which is different from other studies conducted elsewhere in the world, can be explained by the relatively small number of Type 2 diabetes mellitus patients enrolled in the study.

Dyslipidaemia was diagnosed in $55.7 \%$ of the study participants (both with and without comorbidities, $\mathrm{n}=1222$ ), and in $83 \%$ of men with concomitant diseases $(n=820)$. The observed prevalence of dyslipidaemia was similar to the data described in literature. In the Massachusetts Male Aging Study, dyslipidaemia was diagnosed in 55\% of men aged 40 to 79 years. In the European Male Ageing Study, dyslipidaemia was not investigated separately; a group of patients with "One or more concomitant diseases", including coronary heart disease, arterial hypertension, dyslipidaemia and others, was distinguished. Various studies showed a direct correlation of hypogonadism with dyslipidaemia. For example, the Telecom Study and the Rancho Bernardo Study showed that lower level of testosterone was associated with higher LDL and triglyceride levels, and lower HDL level (Simon et al., 1997; Laughlin et al., 2008). Other authors also noted the relationship between dyslipidaemia, metabolic syndrome, and LOH in their publications, and testosterone replacement therapy (TRT) was recommended as an effective method of treatment of metabolic 
syndrome and its components (Winter et al., 2014). In some smaller studies, a correlation between dyslipidaemia and LOH was not shown. For example, in a study that enrolled 247 patients with LOH (average age was 75.8 years), although a trend toward lower levels of testosterone was found in patients with cardiovascular risk factors, this difference was not statistically significant (Ponholzer et al., 2010). Perhaps this was due to the small number of participants in the study. Our study results are in line with those of large studies that showed dyslipidaemia to be more frequent in men with hypogonadism than in eugonadal patients. We established that, regardless of other chronic diseases and men's age, patients with dyslipidaemia had a 15.80-fold higher chance of suffering from hypogonadism compared to men who did not have dyslipidaemia $(p<0.001)$. We also showed that, regardless of other diseases and age, dyslipidaemia decreased the levels of both total and free testosterone by 1.18 and 2.71 units, respectively. Such a significant role of dyslipidaemia can be explained by its involvement in the pathogenesis of several pathological processes, for example, in the development of metabolic syndrome, or endothelial dysfunction.

We recorded metabolic syndrome in $11.4 \%$ of the study participants $(n=1222)$, and in $17 \%$ of participants with concomitant diseases $(n=820)$. Metabolic syndrome was found more frequently in patients with reduced testosterone levels than in eugonadal men, as described in the literature. Wide epidemiological studies enrolling men over 40 years of age, such as the Massachusetts Male Aging Study and European Male Ageing Study, increased prevalence of metabolic syndrome in men with testosterone deficiency was shown (Feldman et al., 1994; Lester and Mason, 2015). Meta-analysis of 20 studies indicated that metabolic syndrome was associated with $\mathrm{LOH}$, and TRT had a positive effect on metabolic control and central adiposity (Corona et al., 2011). Our study revealed that metabolic syndrome decreased the free testosterone level by $6.77 \mathrm{pg} / \mathrm{ml}$, more than by other diseases studied. This can be explained by the fact that several pathogenetic mechanisms causing hypogonadism are enabled in patients with metabolic syndrome: overweight and lipid metabolism disorders, and glucose metabolism disorders. The correlation of these factors with testosterone deficiency is widely described in literature (Phillips et al., 1994; Simon et al., 1997; Laughlin et al., 2008; Ohlsson et al., 2011). Consequently, patients with metabolic syndrome should be vigilant early, already at 40 years of age, concerning the possible development of $\mathrm{LOH}$.

COPD was diagnosed in $8.8 \%$ of the study participants $(\mathrm{n}=$ $1222)$ and in $13 \%$ of men with concomitant diseases $(n=$ 820). In patients with COPD, the testosterone level was statistically significantly lower than in patients without concomitant diseases. Compared to other diseases studied, COPD was found to increase the odds of development of hypogonadism to the greatest extent (24.4-fold); the total testosterone level decreased along with dyslipidaemia to the greatest extent (by 1.18 units) and was the second important cause of decrease of free testosterone level after metabolic syndrome. COPD reduced the free testosterone level by 4.58 units. Similarly, in a study of testosterone level in 69 patients with COPD and a control group, the testosterone level in patients with COPD was statistically significantly lower (Karakou et al., 2013). In addition, a direct correlation between testosterone level and the severity of COPD has been observed (Vertkin, 2013). In a study comprising 70 patients with COPD, prevalent erectile dysfunction and lower testosterone level were observed, but the difference in testosterone level was not statistically significant compared with the control group (Kahraman et al., 2013). Metaanalysis of 2918 patients in nine studies involving patients with COPD, testosterone concentration was lower than in control groups. However, these studies did not involve a large number of participants (Atlantis et al., 2013). In a review of studies (Balasubramanian and Naing, 2012), hypogonadism was found in COPD patients in 22-69\% of cases, and was associated with other systemic problems: osteoporosis, depression, and muscle weakness. Such a significant importance of COPD in developing hypogonadism and decreasing testosterone levels may be due to hypoxia caused by this disease, which in turn interferes with the supply of oxygen to both the testicles and the CNS and harms the synthesis of testosterone. However, some recent studies, according to the author's data, provide controversial information on the aforementioned facts. The difference in results may be related to the small number of participants in the study, and the selection criteria. Data on the efficacy of TRT in COPD patients are controversial and need to be further explored (Balasubramanian and Naing, 2012). Analysis of 140 COPD patients with an average age of $67.4 \pm$ 10.1 years showed that hypogonadism occurred in $58.6 \%$ of men and there was a correlation between testosterone level and the severity of COPD (Mousavi et al., 2012). In large epidemiological studies involving men over 40 years of age, such as Massachusetts Male Aging Study and the European Male Ageing Study, the prevalence of COPD and its association with testosterone deficiency have not been studied.

\section{CONCLUSIONS}

Arterial hypertension, dyslipidaemia, obesity, metabolic syndrome, COPD, and Type 2 diabetes mellitus increase the odds of developing hypogonadism. In patients with this disease serum testosterone levels were found to be lower in comparison to the control group. In addition, the most significant decrease was observed in cases of dyslipidaemia, metabolic syndrome, and COPD. Dyslipidaemia and COPD decreased total testosterone concentration by $1.18 \mathrm{ng} / \mathrm{ml}$ $(p<0.001)$, while the decrease in free testosterone levels was most commonly caused by metabolic syndrome and COPD: by 6.77 and $4.58 \mathrm{pg} / \mathrm{ml}$, respectively. Patients aged 40 years or over, having arterial hypertension, or adiposity, or dyslipidaemia, or metabolic syndrome, or Type 2 diabetes mellitus, or COPD, are recommended for screening of gonadal function condition, in order to prescribe corrective testosterone replacement therapy if necessary. General physicians should pay special attention to patients with meta- 
bolic syndrome, dyslipidaemia, and COPD, as these patients belong to a group with a high risk of development of expressed LOH syndrome.

The authors declare that there is no conflict of interests regarding the publication of this paper.

\section{REFERENCES}

Alberti, K., Echel, H., Grundy, M., Zimmet, P. Z., Cleeman, J. I., Donato, K. A., Fruchart, J. C., James, W. P., Loria, C. M., Smith, S. C. Jr. (2009). Harmonizing the metabolic syndrome. Circulation, 120, 1640-1645.

Amin, S., Zhang, Y., Sawin, C. T., Evans, S. R., Hannan, M. T., Kiel, D. P., Wilson, P. W., Felson, D. T. (2000). Association of hypogonadism and estradiol levels with bone mineral density in elderly. Ann. Intern. Med., 133 (12), 951-963

Anonymous (1996). The European Vertebral Osteoporosis Study. J. Bone Miner Res, 11, 1010-1018.

Anonymous (1999). European Study Group for the Study of Insulin Resistance (EGIR). Diabet Med., 16, 442-444.

Anonymous (2000). WHO. Obesity: Preventing and managing the global epidemic. Report of a WHO Consultation (WHO Technical Report Series 894). Geneva, pp. 8-9.

Anonymous (2018). Overweight and obesity: BMI statistics. Eurostat. Available at: http://ec.europa.eu/eurostat/statistics-explained/index.php?title=Overweight_and_obesity_-_BMI_statistics (accessed 21.08.2018).

Atlantis, E., Fahey, P., Cochrane, B., Wittert, G, Smith, S. (2013). Endogenous testosterone level and testosterone supplementation therapy in chronic obstructive pulmonary disease (COPD): A systematic review and meta-analysis. BMJ Open, 3 (8).

Barrett-Connor, E., Goodman-Gruen, D. (1995). Prospective study of endogenous sex hormones and fatal cardiovascular disease in postmenopausal women. BMJ, 311 (7014), 1193-1200.

Barrett-Connor, E., Von Mühlen, D. G., Kritz-Silverstein, D. (1999). Bioavailable testosterone and depressed mood in older men: The Rancho Bernardo Study. J. Clin. Endocrinol. Metab., 84 (2), 573-577.

Blaya, R., Thomaz, L. D., Guilhermano, F., Paludo Ade, O., Rhoden, L., Halmenschlager, G., Rhoden, E. L. (2016). Total testosterone levels are correlated to metabolic syndrome components. Aging Male, 19 (2), 85-89.

Butrova, S. (1999). Syndrome of insulin resistance in abdominal obesity [Бутрова, С. Синдром инсулинрезистентности при абдоминальном ожирении]. Lechashchi vrach, 7, 32-34 (in Russian).

Falahati-Nini, A., Riggs, B. L., Atkinson, E. J., O'Fallon, W. M., Eastell, R., Khosla, S. (2000). Relative contributions of testosterone and estrogen in regulating bone resorption and formation in normal elderly men. J. Clin. Invest., 106, 1553-1560.

Feldman, H. A., Goldstein, I., Hatzichristou, D. G., Krane, R. J., McKinlay, J. B. (1994). Impotence and its medical and psychosocial correlates: Results of the Massachusetts Male Aging Study. J. Urol., 151 (1), 54-61.

Feldman, I. R., Longcope, C., Derby, C. A., Johannes, C. B., Araujo, A. B., Coviello, A. D., Bremner, W. J., McKinlay, J. B. (2002). Age trends in the level of serum testosterone and other hormones in middle aged men: Longitudinal results from the Massachusetts Male aging study. J. Clin. Endocrinol. Metab., 87 (2), 87-92.

Ferrando, A. A., Sheffield-Moore, M., Yeckel, C. W., Gilkison, C., Jiang, J., Achacosa, A., Lieberman, S. A., Tipton, K., Wolfe, R. R., Urban, R. J. (2002). Urban testosterone administration to older men improves muscle function: Molecular and physiological mechanisms. Amer. J. Physiol. Endocrinol. Metab., 282, 601-607.

Hatzimouratidis, K., Amar, E., Eardley, I., Giuliano, F., Hatzichristou, D., Montorsi, F., Vardi, Y., Wespes, E. (2010). Guidelines on male sexual dysfunction: Erectile dysfunction and premature ejaculation. Eur. Urol., 57 (5), 804-814.

Isidori, A. M., Caprio, M., Strollo, E., Moretti, C., Frajese, G., Isidori, A., Fabbri, A. (1999). Leptin and androgens in male obesity: Evidence for leptin contribution to reduced androgen level. J. Clin. Endocrinol. Metab., 84, 3673-3680.

Isidori, A. M., Giannetta, E., Pozza, C., Bonifacio, V., Isidori, A. (2005). Androgens, cardiovascular disease and osteoporosis. J. Endocrinol. Invest, 28 (10 Suppl), 73-79.

Jockenhovel, F. (1999). Influence of various modes of androgen substitution on serum lipids and lipoproteins in hypogonadal men. Metabolism, 48 (5), 590-596.

Jockenhovel, F. (2004). Male Hypogonadism. Germany International Medical Publishers, Bremen. 188 pp

Kahraman, H., Sen, B., Koksal, N., Kilinē, M., Resim, S. (2013). Erectile dysfunction and sex hormone changes in chronic obstructive pulmonary disease patients. Multidiscip. Respir. Med., 8 (1), 66.

Kaiser, F. E., Morley, J. E. (1994). Gonadotropins, testosterone, and the aging male. Neurobiol Aging, 15 (4), 559-563.

Karakou, E., Glynos, C., Samara, K. D., Msaouel, P., Koutsilieris, M., Vassilakopoulos, T. (2013). Profile of endocrinological derangements affecting PSA values in patients with COPD. In Vivo, 27 (5), 641-649.

Kasperk, C. H., Wergedal, J. E., Farley, J. R., Linkhart, T. A., Turner, R. T., Baylink, D. J. (1989). Androgens directly stimulate proliferation of bone cells in vitro. Endocrinology, 124, 1576-1578.

Katznelson, L., Finkelstein, J. S., Schoenfeld, D. A., Rosenthal, D. I., Anderson, E. J., Klibanski, A. (1996). Increase in bone density and lean body mass during testosterone administration in men with acquired hypogonadism. J. Clin. Endocrinol. Metab., 81 (12), 4358-4365.

Keasl, J. R. (1999). The autonomic nerve supply of male sex organs an important target of circulating androgens. Behav. Brain Res., 105 (1), 81-92.

Khaiv, K. T., Barrett-Connor, E. (1991). Fasting plasma glucose levels and endogenous androgens in non-diabetic postmenopausal women. Clin. Sci. (Lond.), 80 (3), 199-203.

Laughlin, G. A., Barrett-Connor, E., Bergstrom, J. (2008). Low serum testosterone and mortality in older men. J. Clin. Endocrinol. Metab., 93 (1), $68-75$.

Lester, J. F., Mason, M. D. (2015). Cardiovascular effects of hormone therapy for prostate cancer. Drug Healthcare Patient Saf., 7, 129-138.

Lunenfeld, B., Mskhalaya, G., Zitzmann, M., Arver, S., Kalinchenko, S. Tishova, Y., Morgentalerm, A. (2015). Recommendations on the diagnosis, treatment and monitoring of hypogonadism in men. The Aging Male, 18 (1) $5-15$

Mancia, G., Fagard, R., Narkevich, K. et al. (2013). 2013 ESH/ESC Guidelines for the management of arterial hypertension. Eur. Heart J., 34 (28), 2159-2219.

Morales, A., Lunenfeld, Ā. (2002). International Society for the Study of the Aging Male. Investigation, treatment and monitoring of late-onset hypogonadism in males. Official recommendations of ISSAM. International Society for the Study of the Aging Male. Aging Male, 5 (2), 74-86.

Ohlsson, C., Barrett-Connor, E., Bhasin, S., Orwoll, E., Labrie F,, Karlsson, M. K., Ljunggren, O., Vandenput, L., Mellström, D., Tivesten, A. (2011). High serum testosterone is associated with reduced risk of cardiovascular events in elderly men. The MrOS (Osteoporotic Fractures in Men) study in Sweden, 58 (16), 1674-1681.

O’Neiil, T. W., Felsenderg, D., Verlaw, J., Cooper, C., Kanis, J. A., Silman, A. J. (1996). The prevalence of vertebral deformity in European man and women: The European Vertebral Osteoporosis Study. J. Bone Miner Res, 11, 1010-1018.

Phillips, G. B., Pinkernell, B. H., Jing, T. Y. (1994). The association of hy-potestosteronemia with coronary artery disease in men. Arterioscler Thromb, 14 (5), 701-706. 
Požarskis, A., Ērenpreiss, J. (2010). Late-onset hypogonadism: Review of the problem. Proceedings of the Latvian Academy of Sciences, Section B, $64(3 / 4), 93-99$.

Reisman, Y., Porst, H., Lowenstein, L., Tripodi, F, Kirana, P. S. (2015). The ESSM Manual of Sexual Medicine. Medix, Amsterdam. 369 pp.

Rosen, R. C., Cappelleri, J. C., Smith, M. D., Lipsky, J., Peńa, B. M. (1999). Development and evaluation of an abridged, 5-item version of the International Index of Erectile Function (IIEF-5) as a diagnostic tool for erectile dysfunction. Int. J. Impot. Res., 11 (6), 319-326.

Schweiger, U., Deuschle, M., Weber, B., Körner, A., Lammers, C. H., Schmider, J., Gotthardt, U., Heuser, I. (1999). Testosterone, gonadotropin, and cortisol secretion in male patients with major depression. Psychosom. Med., 61 (3), 292-296.

Sib, R., Morley, F. E., Kaiser, F. E., Perry, H. M. 3rd, Patrick, P., Ross, C. (1997). Testosterone replacement in older hypogonadal men: A 12-month randomized controlled trial. J. Clin. Endocrinol. Metab., 82 (6), 1661-1667.

Simon, D., Charles, M. A., Nahoul, K., Orssaud, G., Kremski, J., Hully, V., Joubert, E., Papoz, L., Eschwege, E. (1997). Association between plasma total testosterone and cardiovascular risk factors in healthy adult men: The Telecom Study. J. Clin. Endocrinol. Metab., 82 (2), 682-685.

Tajar, A., Huhtaniemi, I. T., O’Neill, T. W., Finn, J. D., Pye, S. R., Lee, D. M., Bartfai, G., Boonen, S., Casanueva, F. F., Forti, G., Giwercman, A., Han, T. S., Kula, K., Labrie, F., Lean, M. E., Pendleton, N., Punab, M., Vanderschueren, D., Wu, F. C. (2012). Characteristics of androgen deficiency in late-onset hypogonadism: Results from the European Male Aging Study (EMAS). J. Clin. Endocrinol. Metab., 97 (5), 1508-1516.

Takahashi, J., Higashi, Y., LaNasa, J. A., Yoshida, K., Winters, S. J., Oshima, H., Troen, P. (1983). Studies of the human testis. XVIII. Simultaneous measurement of nine intratesticular steroids: Evidence for reduced mitochondrial function in testis of elderly men. J. Clin. Endocrinol. Metab., 56 (6), 1178-1187.

Tchernof, A., Labrie, F., Belanger, A., Prud'homme, D., Bouchard, C., Tremblay, A., Nadeau, A., Després, J. P. (1997). Androstane-3alpha, 17 betadiol glucuronide as a steroid correlate of visceral obesity in men. $J$. Clin. Endocrinol. Metab., 82 (5), 1528-1534.

Tenover, J. S. (1992). Effects of testosterone supplementation in the ageing male. J. Clin. Endocrinol. Metab., 75, 1092-1098.

Tenover, J. S., Matsumoto, A. M., Plymate, S. R., Bremner, W. J. (1987). The effects of aging in normal men on bioavailable testosterone and luteinizing hormone secretion: Response to clomiphene citrate. $J$. Endocrinol. Metab., 65, 1118-1126.

Tenover, J. L. (1998). Male hormone replacement therapy including "andro-pause". Endocrin. Metab. Clin. North Amer., 27, 969-987.

Tibblin, G., Adlerberth, A., Lindstedt, G., Bjorntorp, P. (1996). The pituitary-gonadal axis and health in elderly men: A study of men born in 1913. Diabetes, 45 (11), 1605-1609.

Tivesten, Å., Vandenput, L., Carlzon, D., Nilsson, M., Karlsson, M. K., Ljunggren, Ö., Barrett-Connor, E., Mellström, D., Ohlsson, C. (2014). Dehydroepiandrosterone and its sulphate predict the5-year risk of coronary heart disease events in elderly men. J. Amer. Coll. Cardiol., 64 (17), 1801-1810.

Tonutti, E. (1954). Qualitative and quantitative effect of chorionic gonadotropin on the testicular structure. Sem. Hop, 30 (34), 2135-2142.

Tran Van, P., Baron, R., Vignery, A. (1982). Cellular kinetics of the bone remodelling sequence in the rat. Anat. Rec., 202, 441-451.

Tran Van, P., Vignery, A., Baron, R. (1982). An electron microscopic study of the bone remodelling sequence in the rat. Cell Tissue Res., 225, 283-292.

Van den Beld, A. W., Bots, M., Janssen, J. A., Pols, H. A. P., Lamberts, S. W. J., Grobbee, D. E. (2003). Endogenous hormones and carotid atherosclerosis in elderly men. Amer. J. Epidemiol., 157 (1), 25-31.
Vanderschueren, D., VanHerck, E., Nijs, J., Ederveen, A. G., De Coster, R., Bouillon, R. (1997). Aromatase inhibition impairs skeletal modeling and decreases bone mineral density in growing male rats. Endocrinology, 138, 2301-2307.

Velazquez, E. M., Mendoza, S. G., Wang, P., Glueck, C. J. (1997) Metformin therapy is associated with a decrease in plasma plasminogen activator inhibitor-1, lipoprotein(a), and immunoreactive insulin levels in patients with the polycystic ovary syndrome. Metabolism, 46 (4), 454.

Veldhuis, J. D., Metzger, D. L., Martha, P. M. (Jr.), Mauras, N., Kerrigan, J. R., Keenan, B., Rogol, A. D., Pincus, S. M. (1997). Estrogen and testosterone, but not a nonaromatizable androgen, direct network integration of the hypothalamo-somatotrope (growth hormone)-insulin-like growth factor I axis in the human: Evidence from pubertal pathophysiology and sex-steroid hormone replacement. J. Clin. Endocrinol. Metab., 82 (10), 3414-3420.

Veldhuis, J. D., Urban, R. J., Lizarralde, G., Johnson, M. L., Iranmanesh, A. (1992). Attenuation of luteinizing hormone secretory burst amplitude as a proximate basis for the hypoandrogenism of healthy aging in men. J. Clin. Endocrinol. Metab., 75 (3), 707-713.

Vermeulen, A. (2001). Androgen replacement therapy in the aging males critical evaluation. J. Clin. Endocrinol. Metab., 86 (6), 2380-2390.

Vermeulen, A. (1991). Androgens in the aging male. J. Clin. Endocrinol. Metab., 73, 221-224.

Vermeulen, A., Verdonck, L., Kaufman, J. M. (1999). A critical evaluation of simple methods for the estimation of free testosterone in serum. J. Clin. Endocrinol Metab., 84 (10), 3666-3672.

Vertkin, A. L., Morgunov, L. I., Shakhmanaev, Kh. A. (2013). Hypogonadism and chronic obstructive pulmonary disease. Urologiia, No. 5, 116-118, 120-122 (in Russian).

Von Eckardstein, A., Kliesch, S., Nieschlag, E. (1997). Suppression of endogenous testosterone in young men increases serum levels of high density lipoprotein subclass lipoprotein A-I and lipoprotein(a). J. Clin. Endocrinol. Metab., 82 (10), 3367-3372.

Von Schoultz, B., Carlström, K. (1989). On the regulation of sex-hormone-binding globulin: A challenge of an old dogma and outlines of an alternative mechanism. J. Steroid Biochem., 32 (2), 327-334.

Vestbo, I., Hurd, S. S., Agusti, A. G., Jones, P. W., Vogelmeier, C., Anzueto, A., Barnes, P. J., Fabbri, L. M., Martinez, F. J., Nishimura, M., Stockley, R. A., Sin, D. D., Rodriguez-Roisin, R. (2013). Global strategy for the diagnosis, management, and prevention of chronic obstructive pulmonary disease: GOLD executive summary. Amer. J. Respir. Crit. Care Med., 187 (4), 347-365.

Wakley, G. K., Schutte, (Jr.) H. D., Hannon, K. S., Turner, R. T. (1991). Androgen treatment prevents loss of cancellous bone in the orchidectomized rat. J. Bone Miner Res, 6, 325-330.

Walker, T. C. (1942). Use of testosterone propionate and estrogenic sub-stance in treatment of essential hypertension, angina pectoris and peripheral vascular disease. J. Clin. Endocrinol., 2, 560-568.

Wallock-Montelius, L. M., Villanueva, J. A., Chapin, R. E., Conley, A. J., Nguyen, H. P., Ames, B. N., Halsted, C. H. (2007). Chronic ethanol perturbs testicular folate metabolism and dietary folate deficiency reduces sex hormone levels in the Yucatan micropig. Bill. Reprod., 76 (3), 455-465.

Wang, C., Nieschlag, E., Swerdloff, R., Behre, H., Hellstrom, W. J., Gooren, L. J., Kaufman, J. M., Legros, J. J., Lunenfeld, B., Morales, A., Morley, J. E., Schulman, C., Thompson, I. M., Weidner, W., Wu, F. C. (2009). ISA, ISSAM, EAU, EAA and ASA Recommendations: Investigation, Treatment and Monitoring of Late-Onset Hypogonadism in Males. Int. J. Impot. Res., 21 (1), 1-8.

Watson, R. R., Huls, A., Araghinikuam M., Chung, S. (1996). Dehydro-epiandrosterone and diseases of aging. Drugs Aging, 9 (4), 274-291.

Williamson, D. A., Perrin, L. A. (1996). Behavioural therapy for obesity. Endocrinol. Metab. Clin. North Amer., 25 (4), 943-954. 
Yassin, A. A., Saad, F. (2007). Improvement of sexual function in men with late-onset hypogonadism treated with testosterone only. J. Sex Med., 4 (2), 497-501.

Received 6 March 2018

Accepted in the final form 28 August 2018
Zitzmann, M., Nieschlag, E. (2003). Hypogonadism in the elderly man. Reliable diagnosis and therapy. Internist, 44 (10), 1313-1321 (in German).

\section{VĒLĪNĀ HIPOGONĀDISMA ATTİSTĪBAS İPATNĪBAS VĪRIEŠIEM AR IEKŠǨİAĀM SLIMĪBĀM}

Vēlīns hipogonādisms (VH) ir klīnisks un bioḳīmisks sindroms, kas asociējas ar vecumu un raksturojams ar tipiskiem simptomiem un samazinātu testosterona līmeni asinīs. Vïriešiem pēc 30 gadu vecuma androgēnu deficìta sastopamība ir no 7 līdz $30 \%$. Pētìjuma mērkis bija izpētīt VH izplatību pacientiem ar paralēli un/vai vienlaikus noritošu patoloǵiju: arteriāla hipertensija, adipozitāte, hroniska obstruktīva plaušu slimība (HOPS), metaboliskais sindroms, 2. tipa cukura diabēts, dislipidēmija dažādās ğimenes ārstu un seksologu praksēs un šo slimību ietekmi uz hipogonādisma attīstību. Vīriešiem pēc 40 gadu vecuma tika piedāvāts aizpildīt "Vīrieša novecošanas anketas" (AMS Aging Male Study questionnaires) devin̄ās ğimenes ārstu praksēs un viena ārsta seksologa praksē. Apkopjot AMS anketas datus, tika izdalīta vīriešu grupa, kurai konstatētas VH pazìmes $(n=1222)$. Šiem pacientiem tika noteikts asinīs testosterona un dzimumhormonu saistošā globulīna (DHSG) līmeni. Izmantojot ierakstus ambulatorās kartēs un fizikālu izmeklēšanu, tika izpētītas hroniskas iekškīgas slimības šai pacientu grupai. Pacientiem ar VH pazīmēm pēc AMS anketas datiem un ar blakusslimībām VH laboratoriski diagnosticēts 79\% gadījumu. Pacientiem ar VH pazīmēm pēc AMS anketas datiem un bez blakusslimībām VH diagnosticēts 4,7\% gadījumu. Arteriālā hipertensija, dislipidēmija, aptaukošanās, metaboliskais sindroms, HOPS un 2. tipa cukura diabēts palielina hipogonādisma attīstības izredzes $(p<0,001)$. Arteriāla hipertensija, dislipidēmija, adipozitāte, metaboliskais sindroms, HOPS statistiski nozīmīgi $(p<0,001)$ pazemina kopēja testosterona līmeni attiecīgi par 0,47, 1,18,0,36, 0,67 un 0,18 ng/ml un brīva testosterona lìmeni — attiecīgi par 2,52, $2,71,1,69,6,77$ un 4,58 pg/ml. 2 tipa cukura diabētam nav konstatēta statistiski ticama ietekme uz kopēja un brīva testosterona līmeni $(p=$ $0,95, p=0,10)$. Visnozīmīgākā testosterona līmeņa pazemināšanās tika novērota dislipidēmijas, metaboliskā sindroma un HOPS gadījumos. G̣imenes ārstam savā darbā īpaša uzmanība jāpievērš pacientiem ar šīm slimībām, jo šādi pacienti ietilpst vēlīna hipogonādisma sindroma attīstības augsta riska grupā. 